\title{
Rural Youths' Involvement in Agricultural Production In Delta Central Agricultural Zone: Challenge To Agricultural Extension Development In Delta State
}

\author{
A. Aphunu and C. N. Atoma \\ Dept. of Agric. Extension and Management \\ Delta State Polytechnic, P.M.B. 5, Ozoro \\ E-mail: tonyaphunu@yahoo.co.uk; Mobile: +2348030877533
}

\begin{abstract}
Youths are a formidable force in the agricultural production process, constituting a sizeable proportion of future progressive farmers and better citizens, especially in the rural areas. While their contribution towards attaining food security cannot be underestimated, their apparent lukewarm attitude towards agriculture is a source of concern and challenge to the development of agricultural extension. This study investigates rural youths' involvement in agricultural production activities in Delta Central Agricultural Zone of Delta State. Data were collected with the aid of questionnaire from 88 youths in the study area. Data analyses were through the use of percentages, means and correlation coefficient. Findings from the study showed that more than half (64.8\%) of the youths were resident in rural areas and are mainly farmers (52.3\%) involved mostly in arable crop production (69.3\%). A greater percentage of the respondents (69.3\%) expressed unfavourable attitude towards agriculture. Attitude correlates positively and significantly with participation in agricultural production activities $(r=0.435)$ and influenced youths interest in agricultural activities. The need to provide social amenities and infrastructures that will make the youths live and work in the rural areas is emphasized. Also there is need to stimulate youths' interest in agriculture through effective rural youth agricultural extension programmes.
\end{abstract}

Key words: Rural youths, attitude, agricultural production, agricultural extension, Delta State.

\section{INTRODUCTION}

Nigeria with a population of over 140 million people (NPC, 2006) has an abundant human and natural resources for agricultural production. UNICEF (2008) reported that about $76 \%$ of Nigeria population lives in the rural areas and about $90 \%$ of the rural dwellers are engaged in agricultural production. However, irrespective of these arrays of advantages, the goal of self sufficiency in food production in Nigeria remains an elusive target. According to Nwachukwu (2008) "one of the problems for non-realization of our goal for food sufficiency is the condition of the 
Nigerian farmer and the farming environment". The Nigerian farmer is ageing with an average of 50 years. The problem with this is that the younger generation is not interested in farming. The age and low level of education of average Nigerian farmers correlates with their aversion of risks associated with the adoption of new innovations and hence the very low productive capacity. In the opinion of many, getting youths to take up farming seems a possible panacea to the problem. According to Jibowo and Sotomi (1996), it is expected that with higher level of education, innovation proneness, minimal risk aversion, greater physical strength and less conservativeness, Nigerian youths in agriculture would ensure adequate food production in Nigeria.

Youths represent the most active segment of the population and the engine that do most productive work of the society (Adesope, 1996). The youths have also been identified as constituting the major resource base for any country which wants to embark on any meaningful agricultural and rural development projects (Onuekwusi, 2005). Ugwokwe, Adesope and lbe (2005) also noted that youths have been part of the overall agricultural development process in Nigeria because of the immense contribution of agriculture to the economy. The active participation of youths in various agricultural activities like vegetable production, livestock husbandry, arable farming and crop processing and marketing in different parts of the country has been reported by Adesope (1996). The participation of youths in agriculture correlates to their rural background which makes them well suited for professional and technical work in agriculture.

On the other hand, Adebayo et al (2006) noted that despite their (youths) rich rural life, farming background and experience, rural youths are yet to actively and productively participate in the development of the nation's agricultural sector. This is related to the dearth of viable institutional framework for mobilizing, developing and channeling the unique abilities, experiences and aspirations of rural youths towards agriculture. In the same vein, because traditional agriculture is based on hoe and cutlass, subsistence agriculture hold no interest or appeal for young people wanting to look on neither the land nor do they have any intention of following their parents into poverty (CTA, 1990).

The scenario was worsened by the emergence of petroleum as a foreign exchange earner thereby igniting a chain of reaction that led to the total neglect of development of agriculture at the grassroots level. The consequential effect of the neglect of agricultural sector is the high rate of rural-urban drift of able bodied young men and women and unemployment, youths' restiveness and hooliganisms, especially as being witnessed in the Niger Delta region. The trend is that of an obscured participation of youths in agricultural productive activities. In the context of this study, there is limited documented information on the involvement of youths in agricultural activities.

Against the background of the significance of youths to the agricultural development process and the significant roles of institutionalized framework to enhance youth's participation in agricultural activities, this study was conceived to achieve the following objectives: 
1. identify the socio-economic characteristics of youths involved in agriculture in the study area;

2. ascertain the level of youths' involvement in agricultural activities in the study area;

3. assess the attitude of youths toward agricultural production in the study area;

4. identify the constraints to youths' involvement in agricultural activities in study area and

5. determine the relationship between attitude and involvement in agricultural activities.

\section{METHODOLOGY}

The study was conducted in Delta Central Agricultural zone of Delta State. The zone comprise of ten blocks, according to the State's Agricultural Development Programme (ADP) classification. A multi stage random sampling technique was used for the study because the sampling units occur in strata of blocks and cells. The first stage involved the random selection of five blocks from a total of ten blocks in the zone. These were Ughelli-North, Sapele, Ethiope-West, Isoko-North and Udu blocks, respectively. The second stage involved the random selection of two cells from eight cells in each block to make a total of ten cells sampled. The last stage involved proportionate random selection of ten youth farmers from each cell, through the various communities' organizations and associations.

A total of 100 youth farmers formed the sample size but only 88 copies of respondents' questionnaires were useful for analysis. Data were collected through the use of structured interview schedule. To determine perceived attitude of youths towards agriculture, ten-item statements were presented and assessment based on a four point Likert-type rating scale of strongly agree (1), agree (2), disagree (3) and strongly disagree (4) with a midpoint of 2.50: mean scores that are equal 2.50 or above indicate agreement, while scores less than 2.50 indicate disagreement. Involvement in agricultural activities was measured by using the Awareness, participation, Benefit and Support (APBS) frame work as used by Obasi and Oguche (1995). Participants were given quantitative judgment such that level of involvement is said to be very low if percentage participation indicated by the respondents is between $0-29 \%$, low if $30-44 \%$ moderate if $45-59 \%$, high if $60-79 \%$ and very high if $80-100 \%$. Constraints to youths involvement in agricultural activities was determined by assessing respondents based on a three point Likerttype rating scale of very serious (3), serious (2) and not serious (1), with a midpoint of 2.0. Mean scores equal to 2.0 or above were regarded as serious and vice versa. Statistical tools used to analyze data include percentage, mean score and correlation coefficient. 


\section{RESULTS AND DISCUSSION}

\section{Socio-Economic Characteristics}

Table 1 show that majority of the respondents (53.4\%) were male with a high percentage of the youths between the ages of 21 and 25 years $(73.9 \%)$. The table also shows that more than half $(52.3 \%)$ of the respondents were unmarried and were mainly farmers $(52.3 \%)$. These tallies with the findings of Matthews - Njoku and Ajaero (2006), where $56 \%$ and $44 \%$ of the respondents in their study were single and married, respectively. This implies that agriculture employs a high percentage of youths, especially in the rural areas where agriculture is the major occupation for self reliance and generation of income (Kompmann, 1999). Also, $43.2 \%$ of the youths had secondary school education suggesting that the youths had a moderate level of awareness about agricultural activities as a result of their level of education. Youths generally have greater knowledge acquisition propensity (Jibowo and Sotomi, 1996) and hence they are eager to learn, receptive to new ideas, looking for ways to be productive and searching for avenues to direct their energies. Education is important in creating positive mental attitude towards adoption of modern farming innovations (Benor et al, 1997). Finally, most of the respondents were rural dwellers (64.8\%). This placed them in vantage position in the practice of agriculture and makes efficient use of available natural resources to promote food security.

TABLE 1: Socio-economic characteristics of respondents $(\mathrm{N}=88)$

\begin{tabular}{|c|c|c|}
\hline Characteristics & Frequency & Percentage \\
\hline \multicolumn{3}{|l|}{ Gender } \\
\hline Male & 47 & 53.4 \\
\hline Female & 41 & 46.6 \\
\hline \multicolumn{3}{|l|}{ Age (years) } \\
\hline 20 and below & 18 & 20.5 \\
\hline $21-25$ & 65 & 73.9 \\
\hline Above 25 & 5 & 5.6 \\
\hline \multicolumn{3}{|l|}{ Marital status } \\
\hline Married & 42 & 47.7 \\
\hline Single & 46 & 52.3 \\
\hline \multicolumn{3}{|l|}{ Education } \\
\hline None & 8 & 9.1 \\
\hline Primary & 11 & 12.5 \\
\hline Secondary & 38 & 43.2 \\
\hline Post Secondary & 31 & 35.2 \\
\hline \multicolumn{3}{|l|}{ Occupation } \\
\hline Farming & 46 & 52.6 \\
\hline Civil Service & 16 & 18.2 \\
\hline Wage labour & 6 & 6.8 \\
\hline Teaching & 9 & 10.2 \\
\hline \multirow{2}{*}{\multicolumn{3}{|c|}{ Residence }} \\
\hline & & \\
\hline Rural & 57 & 64.8 \\
\hline Urban & 31 & 35.2 \\
\hline
\end{tabular}

Source: Field Survey Data, 2008 


\section{Youths Involvement in Agricultural Activities}

Table 2 showed that youths were highly involved in arable crop production (69.3\%), farm labour (64.7\%) and crop (palm oil) processing (61.3\%). Youths were moderately engaged in agric business (47.7\%) and poultry production (46.6\%); lowly engaged in horticulture (38.6\%) and cash crop (35.2\%) production and very lowly involved in fish production (11.4\%). The finding implied that youths were more involved in crop production and farm labour supply than livestock production. Gwary, Pur and Bawa (2008) in their study reported that youths are were interested in crop production than livestock, probably due to the short gestation period of the crop varieties produced, which ensures quick turnover. In addition, livestock production could be more capital intensive than crop production, hence the preference for crop production by most youths.

TABLE 2: Distribution of respondents by level of involvement in agricultural activities

\begin{tabular}{lccl}
\hline \multicolumn{1}{c}{ S/N Agricultural activities } & Frequency* $^{*}$ & Percentage (\%) $^{\text {Remarks }}$ \\
\hline Arable crop production & 61 & 69.3 & High \\
Farm labour & 57 & 64.7 &,$"$ \\
Crop (Palm oil ) processing & 54 & 61.3 &, \\
Agric business & 42 & 47.7 & Moderate \\
Poultry production & 41 & 46.6 &,$"$ \\
Horticulture & 34 & 38.6 & Low \\
Cash crop production & 31 & 35.2 &,$"$ \\
Sheep rearing & 12 & 13.6 & Very low \\
Fish production & 10 & 11.4 &,$"$ \\
Goat rearing & 8 & 9.1 &,, \\
\hline
\end{tabular}

${ }^{*}$ Multiple responses

\section{Youth's attitude towards agriculture}

Table 3 shows the mean response on youth's perceived attitude towards agriculture. Youths' agreed that farming is for the school drop-outs and illiterates (Mean $=3.08)$, farming promote poverty (Mean=2.84), farming is a bad business (Mean=2.80), farming is for the less privileged in the society (Mean=2.76), agriculture is meant for the aged (Mean=2.66), and that farming generates low income (Mean=2.64). Overall, majority of the youths expressed negative attitude 
(indicating unfavourable attitude) towards agriculture as a livelihood occupation. The result confirms Amalu (1998) assertion that attitudes towards agriculture and agricultural activities have not changed as much as desired. The consequence, according to Waldie (2001) is that, in as much as youths still continue to see agricultural practice as inferior, unfulfilling and very hard, they would seek whatever seem good for them especially in other non-agricultural sectors in the cities. Rural youths have migrated to the cities in growing numbers and have become consumers rather than producers of food.

\section{TABLE 3: Mean response of youths on attitude towards agricultural activities}

\begin{tabular}{lccc}
\hline Statements & $\begin{array}{c}\text { Mean } \\
\text { response }\end{array}$ & $\begin{array}{c}\text { Std. } \\
\text { deviation }\end{array}$ & Remark \\
\hline
\end{tabular}

Farming is for the school dropouts and illiterates

Farming promote poverty

Farming is a bad business

$3.08 \quad 0.966 \quad$ Agreed

Farming is for the less privileged in the society

Agric. Is meant for the aged

Farming generates low income

$2.84 \quad 0.889$

2.80

0.700

2.76

0.716

$2.66 \quad 0.872$

2.64

0.857

You like farming as a primary occupation

$2.36 \quad 1.045 \quad$ Disagreed

Farming reduces one's status in the society

2.340 .872 ,

Agric. Products attract low prices

$2.22 \quad 0.910$

Farming is stressful

1.80

0.728

,

Table 4 shows the distribution of the respondents on the basis of their perceived attitudes towards participation in agricultural activities. The table shows that majority $(69.3 \%)$ of the respondents perceived agricultural activities negatively, while only $30.7 \%$ expressed positive attitude towards agriculture in the study area. The implication of the findings is that youths are unfavourably disposed to 
participation in agricultural productivity and hence the massive drift to other non agricultural sectors of the economy.

TABLE 4: Summary of levels of attitude towards agriculture

\begin{tabular}{lcc}
\hline \multicolumn{1}{c}{ Attitude level } & Frequency & $\begin{array}{c}\text { Percentages } \\
(\%)\end{array}$ \\
\hline Unfavourable & 61 & 69.3 \\
Favourable & 27 & 30.7 \\
Total & 88 & 100 \\
\hline
\end{tabular}

\section{Constraints to youth's involvement in agricultural activities}

Table 5 indicated that lack of incentives from government (Means $=2.30$ ), insufficient land (Mean =2.12), lack of infrastructure in the rural areas (Mean = 2.10) and inadequate training and extension services (Means $=2.02$ ) were perceived serious constraints hindering youth's involvement in agricultural production activities. Nor and Madukwe (2000) asserted that increased agricultural productivity and enhanced farmers income are only attainable when an effective agricultural extension system is put in place. Lack of infrastructure and essential inputs also hinders youth's participation in agricultural and rural development activities (Onuekwusi and Ottah, 2006).

TABLE 5: Constraints to youths' involvement in agricultural activities

\begin{tabular}{lccc}
\hline \multicolumn{1}{c}{ Constraints } & $\begin{array}{c}\text { Mean } \\
\text { response }\end{array}$ & $\begin{array}{c}\text { Std. } \\
\text { deviation }\end{array}$ & Remarks \\
\hline $\begin{array}{l}\text { Lack of incentives from } \\
\text { government }\end{array}$ & 2.30 & 0.735 & Serious constraint \\
$\begin{array}{l}\text { Insufficient land } \\
\text { Lack of infrastructures in rural } \\
\text { areas }\end{array}$ & 2.12 & 0.820 &,$"$, \\
$\begin{array}{l}\text { Inadequate training and } \\
\text { extension services }\end{array}$ & 2.10 & 0.505 &,$"$, \\
$\begin{array}{l}\text { Insufficient labour } \\
\text { Others }\end{array}$ & 2.02 & 0.869 &,$"$, \\
& 1.88 & 0.849 & $\begin{array}{l}\text { Not serious } \\
\text { constraint }\end{array}$ \\
\hline
\end{tabular}




\section{Relationship between youth's attitude towards agriculture and involvement in agriculture}

Table 6 shows that youth's attitude towards agriculture correlated positively and significantly with involvement in agricultural production activities $(r=0.475)$. The significant relationship could be attributed to a number of factors such as institutional deficiencies (dearth of infrastructures in the rural areas, lack of government support to encourage agriculture, etc) rural - urban migration tendencies, emerging new livelihood interest of youths (which are non - primary productive) generally perceived low and differed reward or feedback of agriculture as a source of livelihood. Farmers attitudes are more likely to correspond with their behaviour; and in most cases, attitude influences a broad range of behaviours (van den Ban and Hawkins, 1996). That majority expressed or exhibited unfavourable attitude towards agriculture as a livelihood activity translates to low or no involvement in agricultural productive activities in the area.

\section{TABLE 6: Summary of the relationship between respondents' attitude} towards agriculture and involvement in agricultural activities

Variable $\quad \begin{aligned} & \text { Correlation } \\ & \text { coefficient }\end{aligned}$ P-value Remark
Attitude towards agriculture
0.475
0.034
Significant

\section{CONCLUSION}

The study revealed that though youths are involved in some agricultural activities in the area, they generally show unfavourable disposition to participating in agricultural activities. This was enhanced by some institutional problems such as lack of government support and poor extension services, and lack of social and infrastructural facilities in the rural areas. The implication, according to Nwachukwu (2008), is that the government has not taken agriculture seriously and the society perceives farmers as old, illiterate people, producing at subsistence level. The youths do not want to be associated with that image. Therefore, making youth livelihood a development target, especially through encouraging active participation or involvement in agriculture, is a sure way of achieving sustainable rural development.

Based on the findings of this study, it is recommended that:

1. Government should stimulate agricultural production by providing extension services directed at rural youths to improve participation in agricultural activities. This could be achieved through bringing to the knowledge of youths relevant and timely agricultural innovations and training them on the methods of utilizing these technologies. In line with this, youth's empowerment programmes should be intensified while at the same time 
encouraging youth's organizations such as young farmers' clubs. This will ensure redirection of youths to diverse areas of agricultural activities.

2. There is need for development planning to put adequate structures in place for youths to appreciate their immediate environment. In this regard, government should provide infrastructures and social amenities in the rural areas to encourage youths to live and work in the rural areas.

\section{REFERENCES}

Adebayo, K., Awotunde, M., Okuneye, P.A. and Okonowo, U.V. (2006) "Assessment of Secondary School Agricultural Education Programme in the Rural Areas of Imo State", Nigerian Journal of Rural Sociology, Vo1.6. Nos. 1 and 2, October, pp.13-22.

Adesope, O.M. (1996). Evaluation of Youths' Participation in Community Development Projects in River State, Nigeria. Unpublished M.Sc. Thesis, Department of Agricultural Economics and Extension, Federal University of Technology, Owerri.

Amalu, U.C. (1998). Agricultural Research and Extension delivery system in subSaharan Africa. Calabar: The University of Calaber press.

Benor, D., Harrison, J.Q. and Baxter, M. (1997). Agricultural Extension: The Training and Visit system. Washington, D.C.2 The World Bank.

Gwary, M.M., Pur, J.T. and Bawa,D.B. (2008). Socio-economic Determinants of Youths' Involvement in Agricultural activities in Askira/Uba Local Government Area of Borno State. In: Ladele, A.A. et al (eds). Policy Advocacy Role in Agricultural and Rural Transformation in Nigeria. Proceedings, 17th Annual Congress of the Nigerian Rural Sociological Association (NRSA), NRCRI, Umudike, 19th-22nd August. Pp.15-23.

Jibowo, A.A. and Sotomi, A.O. (1996). The Youths in Sustainable Rural Development. A Study of Youth Programmes in Odeda Local Government Area of Ogun State. In: Ladele, A.A. et al (eds). Policy Advocacy Role in Agricultural and Rural Transformation in Nigeria. Proceedings, 17th Annual Congress of the Nigerian Rural Sociological Association (NRSA), NRCRI, Umudike, 19th-22nd August.Pp. 54-57.

Kompmann, M. (1999). Sector programmes and how it can contribution to poverty Reduction and Gender Equity. Agriculture and Rural Development, Vo1.6, No. 2, pp. 8 -9.

Matthews - Njoku, E.C. and Ajaero, J.O. (2007). Role of youths in food security in Ikeduru Local Government Area of Imo State, Nigeria. Global Approaches to Extension Practice, Vo1.3, No.1, and pp.36 - 41.

National Population Commission (NPC), (2006). National Population Estimates. Abuja, Nigeria. 
Nor, L.M. and Madukwe, M.C. (2000). Strengthening Co-ordination of Agricultural Programmes between Local Government Areas and the Agricultural Development Programmes (ADPs). In: Olowu, T.A (eds.) Stakeholders participation for Strengthening Agricultural Extension. Proceedings of AESON, pp $106-144$.

Nwachukwu, I (2008). Youth Development for Agriculture and Rural Transformation in Nigeria. Proceedings of NRSA, pp.11-14.

Obasi, N. and Oguche, D. (1995). Innovative Programmes in Rural Development in Nigeria. An Evaluation of the Better Life Programme using the APBS Framework. In Eboh, E. C., Okoye, C.U. and Ayichi, D. (eds). Rural Development in Nigeria: Concept, processes and prospects. Auto-century Publishing Company Ltd, Enugu, Nigeria. Pp.73-85.

Onuekwusi, G. C. (2005). Youth Programme in Extension and Rural Development. In: Nwachukwu and Onuekwusi, G.C. (eds). Agricultural Extension and Rural Sociology. Snaap Press, Enugu. Pp. 197-214.

Onuekwusi, G.C. and Ottah,U.U. (2006). Participation of Youths in Agricultural and Rural Development activities in Edda, Ebonyi State. In Asumugha, G.N., et al (eds). Repositioning Agriculture for sustainable Millennium Development Goals in Nigeria. Proceedings of the $40^{\text {th }}$ Annual Conference of the Agricultural Society of Nigeria (ASN), Umudike, Abia State, $16^{\text {th }}-20^{\text {th }}$ October. Pp. 245-249.

Technical Centre for Agricultural and Rural cooperation (CTA) (1990). Youths and Agricultural Production, June edition. Wageningen, The Netherlands.

Ugwoke, F.O., Adesope, O.M. and Ibe, F.C. (2005). Youths Participation in Farming Activities in Rural Areas of Imo State, Nigeria. Implications for Extension. Journal of Agricultural Extension. 8:136-141.

UNICEF (2008). Draft Country Programme document, Nigeria. E/ICEF/2008//P/L.7. UNICEF, Enugu.

Van den Ban A.W.and Hawkins, H.S. (1996).Agricultural Extension (2 ${ }^{\text {nd }}$ Ed).London: Blackwell Science Ltd.

Waldie, K. (2001). "Youth and Rural Livelihoods". LEISA. Vol. 20, No. 2. New Generation of Farmers. The Netherlands. 